\title{
BIMBINGAN KEAGAMAAN ISLAM TERHADAP WARGA BINAAN LEMBAGA PEMASYARAKATAN KELAS IIA JAMBI
}

\author{
Oleh: \\ Ruslan Abdul Gani*
}

\begin{abstract}
Abstrak
Bimbingan agama di Lembaga Pemasyarakatan menjadi salah satu faktor penting dalam pembinaan warga binaan Lembaga Pemasyarakatan. Pembinaan agama, khususnya Islam, merupakan sarana mengimplementasikan akidah, akhlak serta nilai-nilai yang telah ditentukan oleh agama Islam. ${ }^{1}$ Bimbingan keagamaan Islam juga membantu warga binaan untuk menjadi makhluk sosial, yang berpengaruh positif kepada orang lain. Meskipun pengaruh bimbingan agama tidak terjadi secara langsung, tetapi ia menjadi salah satu faktor penentu bagi setiap perubahan perilaku manusia ketika hidup bermasyarakat, Fungsi pembinaan ini dapat dilihat jika warga binaan Lembaga Pemasyarakatan kelak bebas dari hukuman. Fungsi Pemidanaan tidak lagi sekedar pemenjaraan, tetapi juga merupakan suatu proses rehabilitasi dan reintegrasi sosial warga binaan yang ada di dalam Lembaga Pemasyarakatan. Pelaksanaan bimbingan keagamaan Islam terhadap warga binaan di Lembaga Pemasyarakatan Kelas IIA Jambi sudah dilakukan akan tetapi dalam pelaksanaan masih ditemui beberapa kendala, maka diperlukan upaya yang dilakukan dalam mengatasi kendala dalam pembimbing Keagamaan Islam terhadap Warga binaan di Lembaga Pemasarakatan Kelas II A Jambi yang bertujuan mereka dapat diterima kembali oleh masyarakat dan lingkungannya dan dapat hidup secara wajar seperti sediakala.
\end{abstract}

Kata Kunci : Bimbingan Keagamaan Islam, Warga Binaan, LP Klas II A Jambi

\section{A. Pendahuluan}

Lembaga Pemasyarakatan atau disingkat Lapas adalah sebutan baru penggati sebutan penjara yang dimulai pada tahun 1995 mengikuti Undang-Undang Pemasyarakatan. Lahirnya istilah Lembaga Pemasyarakatan dipilih sesuai dengan visi dan misi lembaga itu untuk menyiapkan para narapidana kembali ke masyarakat. Istilah ini dicetuskan pertama kali oleh Rahardjo, yang menjabat Menteri Kehakiman RI saat itu. Pemasyarakatan dinyatakan sebagai suatu sistem pembinaan terhadap para pelanggar hukum dan sebagai suatu pengejawantahan keadilan yang bertujuan untuk mencapai reintegrasi sosial atau pulihnya kesatuan hubungan antara warga binaan atau narapi dana sesuai dalam Undang-Undang Nomor 12 Tahun 1995 tentang Pemasyarakatan, terpidana adalah seseorang yang di pidana berdasarkan putusan pengadilan yang telah memperoleh kekuatan hukum tetap pemasyarakatan dengan masyarakat.

\footnotetext{
* Pengajar Fakultas Syariah UIN STS JAMBI

${ }^{1}$ Juntika Nurihsan, Achmad Akur Sudianto, Manajemen Bimbingan dan Konseling di SMA, Jakarta; Grasindo, 2005. hal.25
} 
Bimbingan agama di Lembaga Pemasyarakatan menjadi salah satu faktor penting dalam pembinaan warga binaan Lembaga Pemasyarakatan. Pembinaan agama, khususnya Islam, merupakan sarana mengimplementasikan akidah, akhlak serta nilai-nilai yang telah ditentukan oleh agama Islam. ${ }^{2}$ Bimbingan keagamaan Islam juga membantu warga binaan untuk menjadi makhluk sosial, yang berpengaruh positif kepada orang lain. Meskipun pengaruh bimbingan agama tidak terjadi secara langsung, tetapi ia menjadi salah satu faktor penentu bagi setiap perubahan perilaku manusia ketika hidup bermasyarakat. ${ }^{3}$

Bimbingan keagamaan Islam di Lembaga Pemasyarakatan juga telah dibantu oleh kemajuan teknologi informasi yang berkelanjutan. Bimbingan keaagamaan secara Islam adalah ajaran amar ma'ruf nahi mungkar bertujuan menegakkan agama Allah dan menghidupkan sunnah Rasul-Nya tanpa riya', dan sikap munafik. ${ }^{4}$

Fungsi bimbingan keagamaan bagi warga binaan di dalam Lembaga Pemasyarakatan adalah untuk lebih banyak memberikan bekal bagi warga binaan lembaga pemasyarakatan dalam menyongsong kehidupan setelah selesai menjalani masa hukuman (bebas). ${ }^{5}$

Kegiatan keagamaan di dalam Lembaga Pemasyarakatan bukan sekedar untuk menghukum atau menjaga warga binaan tetapi mencakup proses pembinaan agar warga binaan menyadari kesalahan dan memperbaiki diri serta tidak mengulangi tindak pidana yang pernah dilakukan yang bertentangan dengan ajaran agama. ${ }^{6}$

Fungsi pembinaan ini dapat dilihat jika warga binaan Lembaga Pemasyarakatan kelak bebas dari hukuman. Mereka dapat diterima kembali oleh masyarakat dan lingkungannya dan dapat hidup secara wajar seperti sediakala. Fungsi Pemidanaan tidak lagi sekedar pemenjaraan, tetapi juga merupakan suatu proses rehabilitasi dan reintegrasi sosial warga binaan yang ada di dalam Lembaga Pemasyarakatan. ${ }^{7}$

Perkembangan Sistem Pemasyarakatan mulai dilaksanakan sejak tahun 1964.Perubahan sistem terjadi setelah lahirnya UU No 12 Tahun 1995 tentang Pemasyarakatan.Undang-Undang Pemasyarakatan itu menguatkan usaha-usaha untuk

\footnotetext{
${ }^{2}$ Juntika Nurihsan, Achmad Akur Sudianto, Manajemen Bimbingan dan Konseling di SMA, Jakarta; Grasindo, 2005. hal.25

${ }^{3}$ Bakhtiar, Nurhasanah Pendidikan Agama Islam di Perguruan Tinggi, Yogyakarta: Aswaja Pressindo, 2013, hal. 56 .

${ }^{4}$ Abdul Aziz bin Ahmad, Tuhan Tak Pernah Memaksa, Jakarta: Hikmah, 2006, hal. 58.

${ }^{5}$ Prayitno dan Errman Ampti, Dasar- Dasar Bimbingan dan Konseling, Jakarta: Rineka Cipta, 2009.

${ }^{6}$ Fakhrurazi, Pelaksanaan Bimbingan Keagamaan Terhadap Narapidana di Lembaga Pemasyarakatan Klas IIA Teluk Dalam Banjarmasin, Banjarmasin: Institut Agama Islam Negeri Antasari Fakultas Dakwah dan Komunikasi Jurusan Bimbingan dan Penyuluhan Islam. 2010, hal. 53.

${ }^{7}$ Barnawi dan M. Arifin, Peran Lembaga Pemasyarakatan Dalam Memberikan Bimbingan Pada Anak Didik Pemasyarakatan, Jogjakarta: Arrus Media,2012. hal. 61.
} 
mewujudkan suatu sistem pemasyarakatan yang merupakan tatanan pembinaan baik hukum, agama, ekonomi bagi warga binaan pemasyarakatan. ${ }^{8}$

Seorang warga binaan ketika menjalani vonis yang dijatuhkan oleh pengadilan, maka hak-haknya sebagai warga binaan negara akan dibatasi. Sesuai Undang-Undang No.12 Tahun 1995, Narapidana adalah terpidana yang menjalani pidana hilang kemerdekaan di Lembaga Pemasyarakatan.Walaupun terpidana kehilangan kemerdekaannya, tapi ada hak-hak narapidana yang tetap dilindungi dalam sistem pemasyarakatan Indonesia.UU No.12 Tahun 1995 sebagai payung sistem pemasyarakatan Indonesia, menyelenggarakan sistem pemasyarakatan yang bertujuan agar narapidana dapat memperbaiki diri dan tidak mengulangi tindak pidana yang telah dilakukannya.Sistem itu juga bertujuan agar narapidana dapat diterima kembali dalam lingkungan masyarakat. Mereka diharapkan kembali aktif berperan dalam pembangunan serta hidup secara wajar sebagai seorang warga binaan negara. ${ }^{9}$

Proses pembinaan keagamaan di dalam LP dilakukan secara aktif dan bertahap. Seorang warga binaan lazimnya menjalani $2 / 3$ masa pidana yang sebenarnya atau sekurangkurangnya 9 bulan. Pada tahap akhir ini kegiatan didalam LP meliputi: perencanaan, dan pelaksanaan program integrasi yang dimulai sejak berakhirnya tahap lanjutan sampai dengan selesainya masa pidana. Pada tahap ini juga, bagi narapidana yang memenuhi syarat diberikan cuti menjelang bebas atau pembebasan bersyarat. Pembinaan dilakukan diluar Lapas oleh Balai Pemasyarakatan (BAPAS) yang kemudian disebut pembimbingan Klien lembaga Pemasyarakatan. ${ }^{10}$

Narapidana sebagai subjek yang sedang mencari jati dirinya tidak bisa tidak memerlukan bimbingan agama secara terus menerus. Mereka perlu dibantu mengembangkan segenap potensinya melalui pembiasaan bertingkah laku terpuji dan bertanggung jawab, kreatif dan didasari keimanan dan ketaqwaan kepada Allah SWT. Pada fase ini terjadi pencarian jati diri yang membuat warga binaan mengalami kebingungan dalam mencari sosok untuk merujuk.Tokoh agama penting menjadi sosok tauladan dan sumber rujukan bagi warga binaan di Lembaga Pemasyarakatan.

Berdasarkan grandtour penulis di Lembaga Pemasyarakatan Kelas II A Jambi, yang terlibat dalam memberikan bimbingan keagamaan adalah, H. Tarmizi, Hasanuddin, S.Ag.

\footnotetext{
${ }^{8}$ Tim Redaksi Fokus Media, Undang-Undang RI, Jakarta: 2008, hal. 15.

${ }^{9}$ Undang-Undang No.12 Tahun 1995, Tentang Lembaga Pemasyarakatan, hal. 19

${ }^{10}$ Nelson Sihombing,Pola Pembinaan Narapidana Dalam Bidang Keagamaan di Lembaga Pemasyarakatan, Jakarta, Sinar Grafika, 2008.hal. 79.
} 
dari UIN STS Jambi, dari Kemenag Propinsi Jambi adalah Lukman Hakim, Makruf Hanafi, ${ }^{11}$

Adapun sasaran bimbingan keagamaan ini diberikan kepada pertama, masih ada warga binaan LP yang tidak memahami ajaran agamanya. Kedua, perilaku keagamaan warga binaan lapas belum banyak perubahan ketika sudah menjadi warga binaan di lembaga Pemasyarakatan. Bimbingan keagamaan nampak tidak optimal merubah kepribadian warga binaan Lembaga Pemasyarakatan seperti yang diharapkan. Ketiga, lingkungan yang buruk pasca pembinaan di lapas mendorong warga binaan kembali melakukan kejahatan dan menghambat warga binaan untuk hijrah sepenuhnya. ${ }^{12}$

\section{B. Permasalahan}

Berkaitan dengan latar belakang di atas, maka rumusan masalah yang ingin diangkat dalam makalah ini antara lain:

1. Bagaimana pelaksanaan bimbingan keagamaan (Islam)terhadap warga binaan di Lembaga Pemasyarakatan Kelas II A Jambi ?

2. Apa Saja Kendala yang ditemui dalam pelaksanaan bimbingan keagamaan (Islam) terhadap warga binaan di Lembaga Pemasyarakatan Kelas II A Jambi ?

3. Bagaimana upaya yang dilakukan dalam mengatasi kendala dalam bimbingan Keagamaan (Islam) terhadap Warga binaan di Lembaga Pemasarakatan Kelas II A Jambi ?

\section{Pembahasan}

\section{Pelaksanaan Bimbingan Keagamaan(Islam) di Lembaga Pemasyarakatan Kelas II A} Jambi.

Kegiatan bimbingan keagamaan mempunyai peranan penting di Lembaga Pemasyarakatan, karena kegiatan ini berupa kegiatan keagamaan yang akan menambah pengetahuan agama mereka, seperti mengikuti ceramah agama dan pengajian lainnya. Kiprah pembimbing keagamaan di lembaga pemasyarakatan memberikan andil yang cukup besar

\footnotetext{
${ }^{11}$ Grandtour dilakukan pada tanggal 3 Juni 2020

${ }^{12}$ M. Saman, Petugas Bagian Pembinaan Anak Didik Lembaga Pemasyarakatan Kelas II A Jambi , Wawancara 4 Juni 2020.
} 
bagi penanaman nilai-nilai keagamaan bagi para warga binaan sekaligus memupuk hubungan silahturrahmi di antara sesama umat Islam. ${ }^{13}$

Dari wawancara penulis dengan Bapak Dedi Antoni, adapun pelaksanaan bimbingan Keagamaan khususnya Agama Islam yang diberikan di Lembaga Pemasyarakatan Kelas II A Jambi meliputi: ${ }^{14}$

\section{a. Pelaksanaan Bimbingan Keagamaan Melalui Ceramah Agama, Bimbingan Rohani dan Keagamaan}

Bimbingan pembinaan keagamaan Islam baik dalam hal kegiatan ceramah agama, bimbingan rohani dan keagamaan dilaksanakan hampir setiap hampir setiap hari, hanya pelaksanaan bimbingan keagamanaan antara napi laki-laki dan perempuan dilaksanakan dalam waktu yang berbeda. Pelaksanaan bimbingan keagamaan Islam berpusat pada masjid yang ada di dalam Lembaga Pemasyarakatan Kelas Kelas II A Jambi, dan pelaksanaan kegiatan merupakan wujud dari kerjasama Lapas dengan instansi dan organisasi diluar, seperti Kementerian Agama Provinsi Jambi, UIN STS Jambi.

Mengenai bimbingan keagamaan yang telah diberikan oleh Lembaga Pemasyarakata Kelas II A Jambi, dawi wawancara penulis dengan Salah seorang Warga Binaan Lapas Kelas II A Jambi, Bapak H. Tendrisyah, menjelaskan; Benar ada bimbingan keagamaan yang dilakukan oleh pihak Lembaga Pemasyarakatan terhadap warga binaanyang dilakukan dua minggu sekali jadwal yang sudah ditentukan, ${ }^{15}$ kegiatan keagamaan ini juga bukan hanya dilakukan oleh pihak lapas, melainkan juga melakukan koordinasi dengan pihak Departemen Agama dan lembaga lainya untuk lebih memaksimalkan program pelaksanaan bimbingan keagamaan.

Selanjutnya dari wawancara penulis dengan salah seorang Pegawai Lembaga Pemasyarakatan Kelas II A Jambi menjelasan : Pelaksanaan bimbingan keagamaan di Lapas Kelas II A Jambi dilakukan sesuai dengan jadwal yang telah ditentukan sehingga pelaksanaannya dapat di monitor dengan baik, sehingga pelaksanaannya tidak bertabrakan dengan kegiatan lainnya. ${ }^{16}$

\footnotetext{
${ }^{13}$ Sudin, Pengaruh Bimbingan Rohani Islam Terhadap Keberagamaan Narapidana di Lembaga Pemesyarakatan, Kelas IIB Indramayu, Jakarta: UIN Syarif Hidayatullah: 2014.hal. 62.

${ }^{14}$ Dedi Antoni, Petugas Bagian Pembinaan Anak Didik Lembaga Pemasyarakatan Kelas II A Jambi, Wawancara 4 Juni 2020.

${ }^{15}$ H. Tendrisyah, Warga Binaan pada Lebaga Pemasyarakatan Kelas II A Jambi, Wancara penulis 4 Juni 2020.

${ }^{16}$ Observasi Penulis 19 Mei 2018
} 
Lebih jelasnya kegiatan pembinaan keagamaan tersebut dapat dilihat dari susunan jadwal Acara yang telah ditentukan oleh Bidang Pembinaan Keagamaan Lembaga Pemasyarakatan Kelas II A Jambi berikut di bawah ini:

Tabel 1:

Jadwal Bimbingan Keagamaan di Lapas Kelas II A Jambi

\begin{tabular}{|c|c|c|c|c|}
\hline No & Minggu & Waktu & Kegiatan & Pelaksana \\
\hline 1 & $\mathrm{Ke}-1$ & $07 .{ }^{00}$ sampai $10.30^{00}$ & $\begin{array}{lc}\begin{array}{l}\text { Ceramah } \\
\text { siraman } \\
\text { belajar Fiqih }\end{array} & \begin{array}{c}\text { Agama, } \\
\text { rohani, }\end{array} \\
\end{array}$ & $\begin{array}{l}\text { Kementrian Agama } \\
\text { dan Pembina Lapas }\end{array}$ \\
\hline 2 & $\mathrm{Ke}-2$ & $08 .{ }^{00}$ sampai $10.30^{00}$ & $\begin{array}{l}\text { Bimbingan Sholat } \\
\text { Sunah } \\
\text { (Taubat),amalan } \\
\text { pribadi Zikir dan } \\
\text { Ceramah }\end{array}$ & $\begin{array}{l}\text { Kementrian Agama dan } \\
\text { Pembina Lapas }\end{array}$ \\
\hline 3 & $\mathrm{Ke}-3$ & $07 .{ }^{00}$ sampai $10.30^{00}$ & $\begin{array}{l}\text { Bimbingan Mengaji, } \\
\text { belajar } \quad \text { tajwid, } \\
\text { Halaqoh Al-Quran }\end{array}$ & $\begin{array}{l}\text { Kementrian Agama dan } \\
\text { Pembina Lapas }\end{array}$ \\
\hline 4 & $\mathrm{Ke}-4$ & $07 .{ }^{00}$ sampai $10.30^{00}$ & $\begin{array}{ll}\text { Ceramah } & \text { Agama, } \\
\text { siraman } & \text { rohani, } \\
\text { belajar Fiqih } & \end{array}$ & $\begin{array}{l}\text { Kementrian Agama } \\
\text { dan Pembina Lapas }\end{array}$ \\
\hline
\end{tabular}

Sumber Data: Las Kelas II Jambi Juni 2020

Berdasarkan Tabel I tersebut di atas, dapatlah diketahui bahwa jadwal pelaksanaan bimbingan keagamaan untuk anak didik di Lembaga Pemasyarakatan Kelas II A Jambi sebulan 4 (empat) kali diberikan kepada para anak didik pemasyarakatan dan kepada mereka diwajibkan mengikuti kegiatan keagamaan dengan agenda kegiatan yang berbeda-beda.

\section{b. Pelaksanaan Bimbingan Keagamaan Melalui Pembelajaran Al-Quran, Belajar Tajwid dan Fiqih}

Pelaksanaan bimbingan pembelajaran Al-Quran, tajwid dan Fiqih Alquran pada umumnya dilaksanakan 1 kali dalam seminggu, biasanya dilakukan pada hari Jumat. Adapun kegiatan pembelajaran berdasarkan materi tentang Alquran, terbagi menjadi beberapa macam, yaitu: pembelajaran membaca dengan tajwid yang benar, pembelajaran mengenai isi kandungan Alquran dan belajar tentang hukum Fiqih.

Berdasarkan wawancara penulis dengan salah satu napi menjelaskan:

Pelaksanaan bimbingan keagamaan ini memang sering dilakukan secara rutin, kegiatan tersebut seperti belajar membaca Al-Quran, mendengarkan ceramah, belajar hukum Fiqih dan langsung dipraktekan dalam kehidupan sehari-hari, dengan adanya bimbingan 
keagamaan ini saya sudah mulai terbiasa mengerjakan sholat 5 waktu dan memahami ajaranajaran agama dengan cukup mendalam. ${ }^{17}$

Pelaksanaan bimbingan keagamaan melalui berbagai pembelajaran yang diasuh oleh penyuluh atau petugas lapas dan dari departemen agama biasanya dimulai dengan praktik langsung, misalnya ketika diadakan kegiatan membaca Al-Quran, maka para napi dibimbing untuk memperdengarkan, membaca bersama, kemudian bergantian dalam membacanya. Pada kegiatan itu, dimasukkan pelajaran-pelajaran tentang tajwid dan tata cara membaca huruf dapat dikuasi serta dapat memahami makna dari ayat yang dibacanya.

Sebagian penyuluh dari kementrian agama biasanya juga menyampaikan tentang isi kandungan ayat yang telah dibaca dan menyampaikan motivasi-motivasi kepada peserta didik dengan menafsirkan ayat-ayat tersebut. Sedangkan pembelajaran yang diasuh langsung oleh Pembina dari lapas berlangsung pada pembelajaran Alquran yang sifatnya membaca lancar.

\section{c. Pelaksanaan Bimbingan Keagamaan Melalui Konsultasi Bimbingan Individual, Bimbingan Amalan dan Siraman Rohani}

Kegiatan bimbingan keagamaan dalam hal konsultasi ini sering terlihat setelah ceramah agama ataupun kegiatan lainnya yang mendatangkan Pembina dari luar lapas, jika itu mengenai keagamaan. Mengenai hal ini wawancara peneliti masih dengan petugas Lembaga Permasyarakatan Kelas II A Jambi Bapak M. Saman menjelaskan sebagai berikut:

Bimbingan keagamaan yang dilakukan untuk para narapidana di lapas ini juga memberikan peluang kepada para napi untuk konsultasi tentang permasalahan yang dihadapi, kegiatan ini untuk mengetahui beban mental para napi baik ketika menjalani masa hukuman ataupun ketika nanti mereka kembali kemasyarakat, bimbingan dalam bentuk konsultasi ini biasanya dilakukan secara individu dan ada juga dilakukan secara berkelompok." ${ }^{\prime 18}$

Apabila permasalahan yang dihadapi oleh narapidana itu berkaitan dengan keluarga, sering mereka konsultasi dengan para Pembina yang ada di Lapas. Kegiatan ini bisa dibagi menjadi 2 macam, yakni konseling secara kelompok seperti konsultasi pada saat setelah ceramah agama atau yang lainnya, dan konsultasi secara pribadi, yang biasanya mengenai keluarga.

2. Kendala yang ditemui dalam pelaksanaan bimbingan keagamaan Islam Terhadap warga binaan di Lembaga Pemasarakatan Kelas II A Jambi.

${ }^{18}$ H.Suparto, Wawancara dengan Penulis 19 Mei 2018
}

${ }^{17}$ M. Taher, Warga Binaan Anak Didik Pemasyarakatan Kelas II A Jambi, Wawancara tanggal 4 
Mengenai kendala yang ditemui dalam pelaksanaan bimbingan keagamaan Islam warga binaan di Lembaga Pemasarakatan Kelas II A Jambi dari wawancara penulis dengan Bapak Kepala Pemasyarakatan Kelas II A Jambi antara lain.

a. Terbatasnya Dana Dalam melakukan Pembinaan Keagamaan.

b. Kesibukan Tenaga Pembimbing

c. Masih kurangnya Tenaga/Personil dalam Melakukan Pembinaan.

d. Rendahnya Wawasan dan Kesadaran Beragama.

e.. Sarana dan Prasarana yang Masih terbatas. ${ }^{19}$

Lebih jelasnya mengenai 5(lima) kendala yang ditemui dalam melakukan bimbingan keagamaan Islam di Lembaga Pemasyarakatan Kelas II A Jambi, dapat lihat penjelasan berikut di bawah ini.

\section{a. Terbatasnya Dana Dalam melakukan Pembinaan Keagamaan}

Bila dilihat dari kondisi Anak didik Pemasyarakatan yang ada di Lembaga Pemasyarakatan Kelas II A Jambi saat ini dimana dari data yang penulis peroleh dimana jumah nara pidana (penghuni Lapas saat ini total keseluruhannya adalah sebanyak 861 orang. Sedangkan yang beragama Islam sebanyak 798 orang.

Dengan jumlah yang sangat tersebut dibandingkan dengan dana pembinaan yang dianggarkan tentunya menjadi kendala bagi petugas dalam memberikan pembinaan terhadap warga binaan tersebut. Terlebih dimana covid 19 hampir seluruh instansi anggarannya banyak yang dikurangan termasuk di kementerian kehakiman. Dengan dana yang terbatas sehingga kegiatan pembinaan mengalami kendala.

\section{b.Kesibukan Tenaga Pembimbing}

Dalam kaitan dengan lemahnya perhatian terhadap masalah pelaksanaan bimbingan keagamaan karena masalah kesibukan pembimbing keagamaan, maka masalah ini menjadi kendala, karena dengan kesibukan mereka kurang perhatian untuk mengajarkan agama kepada para warga binaan.

Berdasarkan wawancara dengan Bapak Kalapas Kelas II A Jambi, mengatakan:

Adapun yang menjadi kendala dalam pembentukan sikap keagamaan warga binaan di lembaga pemasyarakatan adalah jarangnya hadir para ustadz dalam memberikan pengajian. Karena ustadz yang ditunjuk kadang-kadang banyak yang tidak mengisi acara dikarenakan kesibukan mereka dengan kegiatan mereka di luar. Pada hal tenaga mereka sangat dibutuhkan. Karena dengan didatangkannya ustadz dari luar lembaga pemasyarakatan

\footnotetext{
${ }^{19}$ Yusran Saad, Kepala Pemasyarakatan Kelas II Jambi, Wawancara Tanggal 5 Juni 2020.
} 
bisa membangkitkan rasa gairah para warga binaan untuk mengikuti pengajian di lembaga pemasyarakatan." 20

\section{c. Masih kurangnya Tenaga/Personil dalam Melakukan Pembinaan.}

Bila dilihat dari jumlah Anak didik Pemasyarakatan Kelas II A Jambi yang ada saat ini dimana total keseluruhan berjumlah 861 orang disbanding dengan petugas lapas yang ada kurang lebi 78 orang sedangkan yang bertugas di bidang pembinanaan keagamaan kurang lebih hanya ada 10 orang hal ini tentunya menjadi kendala dalam melakukan pembinaan bimbingan keagamaan.

Menurut Bapak M. Daman memang benar masalah tenaga yang ada di bagian pembinaan sangat terbatas sekali tidak seimbang dengan jumlah napi yang saat ini berjumlah 861 orang. Untuk itu perlu dilakukan penambahan petugas, sehingga pelaksanaan pembinaan dapat berjalan lancar.

\section{d. Rendahnya Wawasan dan Kesadaran Beragama}

Masalah pengetahuan agama dan pengalaman sangat mempengaruhi untuk mengajarkan ilmu agama kepada para warga binaan. Khususnya dalam cara maupun pola pembimbing keagamaan di Lembaga Pemasyarakatan Kelas II A Jambi dalam memberikan bimbingan agama kepada para warga binaan. Karena dengan tingkat pengetahuan agama yang rendah sangat kurang, sehingga sangat sulit bagi penceramah dalam memberikan bimbingan pada warga binaan di lembaga pemasyarakatan kelas II A Jambi.

Hasil wawancara dengan Bapak Dedi Antoni bagian pembimbing keagamaan yang mengatakan sebagai berikut:

Kebanyakan para warga binaan di lembaga pemasyarakatan kelas II A Jambi berpendidikan rendah, sehingga untuk belajar sholat sesuai tuntutan agama Islam masih kurang, maka pembimbing keagamaan di lembaga pemasyarakatan kelas II A Jambi kesulitan, karena banyak dari para warga binaan yang tidak mengerti atau memahami cara membaca Al-Qur'an sehingga sulit mengajarkan bacaan sholat."21

\section{e. Sarana dan Prasarana yang Masih Terbatas}

Sarana dan prasarana merupakan alat pendukung yang sangat pentinga dalam melakukan suatu aktifitas, tanpa sarana dan prasarana yang mendukung, maka pelaksanaan

\footnotetext{
${ }^{20}$ Yusran Saad, Kepala Pemasyarakatan Kelas II Jambi, Wawancara Tanggal 5 Juni 2020.

${ }^{21}$ Dedi Antoni, Petugas Bagian Pembimbing Keagamaan Lembaga Pemasyarakatan Kelas II A Jambi, Wawancara Penulis 4 Juni 2020.
} 
kegiatan tidak dapat berjalan dengan baik sama halnya dalam melaksanakan kegiatan bimbingan keagamaan (islam) di Lembaga Pemasyarakatan Kelas II A Jambi.

Bila dilihat dari sarana yang prasarana yang ada di Lembaga Pemasyarakatan Kelas II A Jambi dalam melakukan bimbingan keagamaan dimana alat pengeras suara Mik suaranya kurang kerang, kipas angin banyak yang tidak berfungsi lagi sehingga kundisi ruangan dialam masjid panas,

\section{Upaya yang dilakukan dalam mengatasi kendala dalam pembimbing Keagamaan Islam terhadap Warga binaan di Lembaga Pemasarakatan Kelas II A Jambi}

Dengan adanya beberapa kendala yang ditemui dalam pelaksanaan bimbingan keagamaan Islam terhadap warga binaan di Lembaga Pemasarakatan Kelas II A Jambi, agar pelaksanaan pembinaan yang dilakukan berjalan dengan lancar dan tujuan dari pembinaan tersebut tercapai yakni meningkatkan ketaatan beribadah dan dapat membaca Kitab Suci Al-Quran dengan baik dan lancar, maka perlu upaya yang dilakukan dalam mengatasi kendala yang terjadi.

Adapun Upaya yang dilakukan oleh Lembaga Pemasyarakatan Kelas II A Jambi dalam mengatasi kendala yang ditemui antara lain.

a. Terbatasnya Dana Dalam melakukan Pembinaan Keagamaan

Upaya yang dilakukan oleh Pihak Lembaga Pemasyarakatan Kelas II A Jambi adalah telah mengajukan kepada Kementerian Hukum dan Hak Asasi Manusia untuk menambah anggaran pembinaan sehingga dalam melakukan bimbingan keagamaan dapat berjalan dengan lancar.

b. Kesibukan Tenaga Pembimbing

Untuk mengatasi hal tersebut, maka petugas pembimbing dari Lembaga Pemasyarakatan Kelas II A Jambi akan melakukan evaluasi terhadap petugas dari luar yang kurang aktif dalam melaksanakan tugas sebagaimana yang telah ditetapkan dalam Jadwal yang telah disusun. Kedepannya yang kurnag aktif tidak akan dipakai lagi.

c. Masih kurangnya Tenaga/Personil dalam Melakukan Pembinaan.

Upaya yang dilakukan oleh Pihak Lembaga Pemasyarakatan Kelas II A Jambi adalah telah mengajukan kepada Kementerian Hukum dan Hak Asasi Manusia 
untuk menambah petugas/Peronil sehingga dalam melakukan bimbingan keagamaan dapat berjalan dengan lancar.

d. Rendahnya Wawasan dan Kesadaran Beragama

Guna menambah wawasan keagamaan dari anak didik pemasyarakat yang ada di Lapas Kelas II A Jambi, upaya yang dilakukan oleh Lapas Kelas II A Jambi adalah kedepannya akan meningkat kwantitas pelaksanaan kegiatan bimbingan keagamaan dimana dari seminggu 1 kali kegiatan rencanakan akan diusulkan prekwensinya menjadi 2 (dua) kali satu minggu

e. Sarana dan Prasarana Yang masih Kurang

Agar pelaksanaan bimbingan keagamaan berjalan dengan lancar dan peserta mengikuti lebih banyak lagi, pihak lembaga pemasyarakat telang menganggarkan biaya yang berkaitan dengan kelengkapan sarana dan prasarana yang masih dirasakan kurang diantaranya Kipas angin akan ditambah lagi jumlahnya, pengeras suara akan diganti dengan yang lebih tinggi lagi frekwensinya sehingga dapat didengar dengan jelas dan lantang bagi anak didik pemasayarakatan.

\section{Kesimpulan}

Kesimpulan yang dapat ditarik dari uraian pada pembahasan sebelumnya adalah:

1. Pelaksanaan bimbingan keagamaan Islam terhadap warga binaan di Lembaga Pemasyarakatan Kelas IIA Jambi sudah dilakukan akan tetapi dalam pelaksanaan masih ditemui beberapa kendala.

2. Kendala yang ditemui dalam pelaksanaan bimbingan keagamaan Islam warga binaan di Lembaga Pemasarakatan Kelas II A Jambi antara lain:

a. Terbatasnya Dana Dalam melakukan Pembinaan Keagamaan.

b. Kesibukan Tenaga Pembimbing

c. Sarana dan Prasarana yang Masih terbatas.

d. Masih kurangnya Tenaga/Personil dalam Melakukan Pembinaan.

3. Upaya yang dilakukan dalam mengatasi kendala dalam pembimbing Keagamaan Islam terhadap Warga binaan di Lembaga Pemasarakatan Kelas II A Jambi.

a. Menambah anggaran pembinaan sehingga dalam melakukan bimbingan keagamaan dapat berjalan dengan lancar. 
b. Melakukan evaluasi terhadap petugas dari luar yang kurang aktif dalam melaksanakan tugas sebagaimana yang telah ditetapkan dalam Jadwal yang telah disusun.

c. Perlu ditingkatkan sarana dan prasarana ayan ada seperti Mike, masih kipas angin yang sangat diperlukan dalam melaksanakan kegiatan pembinaan keagamaan.

d. Mengajukan kepada Kementerian Hukum dan Hak Asasi Manusia untuk menambah petugas/Peronil.

\section{E. DAFTAR PUSTAKA}

Arikunto, Suharsimi, Manajemen Penelitian, Jakarta: Rineka Cipta, 2010.

Bakhtiar, Nurhasanah, Pendidikan Agama Islam di Perguruan Tinggi, Yogyakarta: Aswaja Pressindo, 2013

Barnawi dan M. Arifin, Peran Lembaga Pemasyarakatan Dalam Memberikan Bimbingan Pada Anak Didik Pemasyarakatan, Jogjakarta: Arrus Media, 2012.

Emizir, Metodologi Penelitian Pendidikan Kuantitatif dan Kualitatif, Jakarta: PT. Raja Grafindo Persada, 2008.

Fakhrurazi, Pelaksanaan Bimbingan Keagamaan Terhadap Narapidana di Lembaga Pemasyarakatan Klas IIA Teluk Dalam Banjarmasin, Banjarmasin: Institut Agama Islam Negeri Antasari Fakultas Dakwah dan Komunikasi Jurusan Bimbingan dan Penyuluhan Islam. 2013.

Juntika Nurihsan, Achmad Akur Sudianto, Manajemen Bimbingan dan Konseling di SMA, Jakarta, 2005.

Moleong, Lexsi J, Metode Penelitian Kualitatif Bandung:Remaja Rosdakarya, 2006.

Nelson Sihombing, Pola Pembinaan Narapidana Dalam Bidang Keagamaan di Lembaga Pemasyarakatan, Jakarta, Sinar Grafika, 2008.

Prayitno dan Errman Ampti, Dasar- Dasar Bimbingan dan Konseling, Jakarta: Rineka Cipta, 2009.

Sudin, Pengaruh Bimbingan Rohani Islam Terhadap Keberagamaan Narapidana di Lembaga Pemesyarakatan, Kelas IIB Indramayu, Jakarta: UIN Syarif Hidayatullah: 2014. 